\title{
Konsentrasi Asam Lemak Tidak Teresterifikasi (Nonesterified Fatty Acid, NEFA), Albumin, Kalsium dan Fosfor Dalam Plasma Sebagai Indikator Status Nutrisi Sapi Perah Laktasi (Concentrations of Plasma NEFA, Albumine, Calcium and Phosphor as Indicator Nutrition Status of Lactating Dairy Cattle)
}

\author{
Andi Murlina Tasse* dan Fuji Astuty Auza \\ Laboratorium Jurusan Peternakan \\ Fakultas Peternakan UHO Kendari \\ andimurlinatasse@gmail.com
}

\begin{abstract}
The observation aims was to know nutrition status of lactating dairy cattle based on concentration of NEFA (Nonesterified Fatty Acid), albumine, calcium, and phosphor in plasma. Thirty two head dairy cattle on second lactating period was used to up take blood plasma. T test and regression equal were used to determinate range of its concentration. The results of observation were mean and range of NEFA concentration $0.17 \mathrm{mEq} . \mathrm{L}^{-1}$ and 0.11 to $0.22 \mathrm{mEq} . \mathrm{L}^{-1}$, albumine $2.69 \mathrm{~g} \%$ and 2.51 to $2.87 \mathrm{~g} \%$. Then, mean and range of plasma calcium concentration $9.39 \mathrm{mg} \%$ and 8.90 to $9.88 \mathrm{mg} \%, 8.60$ and 8.10 to $9.10 \mathrm{mg} \%$ of plasma phosphor concentration. Regression equal of plasma NEFA ( $\mathrm{Y}$ ) body weight $\left(\mathrm{X}_{1}\right)$, milk yield $\left(\mathrm{X}_{2}\right)$ is $\mathrm{Y}=0.163 \mathrm{X}_{1}+0.215$ $\mathrm{X}_{2}\left(\mathrm{R}^{2}=11.2 \%, \mathrm{P}>0.05\right)$. Regression equal of plasma albumine $(\mathrm{Y})$, body weight $\left(\mathrm{X}_{1}\right)$, milk yield $\left(\mathrm{X}_{2}\right)$ is $\mathrm{Y}=0.197 \mathrm{X}_{1}+0.006 \mathrm{X}_{2}\left(\mathrm{R}_{2}=12.3 \%, \mathrm{P}>0.05\right)$. Regression equals of plasma calcium $(\mathrm{Y})$, body weight $\left(\mathrm{X}_{1}\right)$, milk yield $\left(\mathrm{X}_{2}\right)$ is $\mathrm{Y}=-0.099 \mathrm{X}_{1}+0.389 \mathrm{X}_{2}\left(\mathrm{R}^{2}=11.9 \%, \mathrm{P}>0.05\right)$, plasma phosphor $(Y)$, body weight $\left(X_{1}\right)$, milk yield $\left(X_{2}\right)$ is $Y=0.72 X_{1}+0.394 X_{2}\left(R^{2}=19.2 \%, P>0.05\right)$. Therefore, energy reserve (concentration of NEFA), calcium and phosphor in plasma were most requirement to increased milk yield.
\end{abstract}

Key words: NEFA, status of nutrition, lactation, dairy cattle, milk yield

\begin{abstract}
ABSTRAK
Tujuan penelitian ini adalah untuk mengetahui status gizi sapi perah laktasi didasarkan pada konsentrasi NEFA (nonesterified Asam Lemak), albumin, kalsium, dan fosfor dalam plasma. Tiga puluh dua sapi perah kepala di periode menyusui kedua digunakan untuk up mengambil plasma darah. Uji $\mathrm{t}$ dan regresi sama digunakan untuk berbagai penentu dari konsentrasi. Hasil pengamatan yang berarti dan berbagai konsentrasi NEFA $0.17 \mathrm{mEq} . \mathrm{L}-1$ dan $0,11-0,22 \mathrm{mEq} . \mathrm{L}-1$, albumin $2.69 \mathrm{~g} \%$ dan 2,51-2,87 g\%. Kemudian, mean dan berbagai konsentrasi kalsium plasma $9.39 \mathrm{mg} \%$ dan 8,90-9,88 mg\%, 8.60 dan 8,10-9,10 mg\% dari konsentrasi fosfor plasma. Regresi sama berat plasma NEFA (Y) tubuh (X1), produksi susu (X2) adalah $\mathrm{Y}=0,163 \mathrm{X} 1+0,215 \mathrm{X} 2$ $(\mathrm{R} 2=11,2 \%, \mathrm{P}>0,05)$. Regresi sama plasma albumin $(\mathrm{Y})$, berat badan $(\mathrm{X} 1)$, produksi susu $(\mathrm{X} 2)$ adalah $\mathrm{Y}=0,197 \mathrm{X} 1+0,006 \mathrm{X} 2(\mathrm{R} 2=12,3 \%, \mathrm{P}>0,05)$. Regresi sama plasma kalsium $(\mathrm{Y})$, berat badan $(\mathrm{X} 1)$, produksi susu $(\mathrm{X} 2)$ adalah $\mathrm{Y}=-0,099 \mathrm{X} 1+0,389 \mathrm{X} 2(\mathrm{R} 2=11,9 \%, \mathrm{P}>0,05)$, plasma fosfor (Y), berat badan (X1), produksi susu (X2) adalah $\mathrm{Y}=0.72 \mathrm{X} 1+0,394 \mathrm{X} 2(\mathrm{R} 2=19,2 \%, \mathrm{P}>$ 0,05 ). Oleh karena itu, cadangan energi (konsentrasi NEFA), kalsium dan fosfor dalam plasma yang paling persyaratan untuk peningkatan produksi susu.
\end{abstract}

Kata kunci: NEFA, status gizi, laktasi, sapi perah, produksi susu 


\section{PENDAHULUAN}

Kebutuhan nutrisi sapi laktasi didasarkan atas bobot badan dan tingkat produksi (NRC, 2001) sedangkan ketersediaan biologis menggambarkan ketersediaan nutrisi langsung dapat dimanfaatkan oleh ternak untuk memenuhi kebutuhannya (Mc Namara et al., 1995; Fronk et al., 1980). Disisi lain, plasma darah merupakan salah satu komponen darah yang mengangkut substansi hasil perombakan lisis dan sintesa dalam jaringan tubuh (Mc Namara and Hillers, 1986) sehingga kadar komponen kimia dalam jaringan dapat menunjukkan status nutrisi sapi laktasi (Baldwin et al., 1994).

Asam lemak tidak teresterifikasi yang lebih dikenal dengan nama NEFA (non esterified fatty acid) merupakan hasil perombakan cadangan lemak berupa triasilgliserol/trigliserida dalam jaringan adiposa/depo lemak, dapat menghasilkan energi melalui oksidasi dalam jaringan hati dan otot. Bila ternak kekurangan energi karena asupan energi tidak mencukupi kebutuhan, maka cadangan energi berupa lemak akan dirombak menjadi NEFA dan gliserol (Hardjasasmita, 1997) yang dapat dijadikan sebagai sumber energi sapi laktasi (Tasse, 2014).

Albumin merupakan salah satu protein plasma mempunyai peranan penting sebagai pengangkut beberapa substansi dalam darah (Swenson 1984), diantaranya NEFA (Mc Nawara et al., 1995). Albumin juga merupakan sumber asam amino untuk sintesa protein jaringan tubuh (Belyea et al., 1986 ; Guyton, 1983), dan sumber asam amino untuk sintesa protein susu dalam jaringan mamari sapi laktasi (Tasse, 2014). Kadar albumin yang rendah dalam darah mengindikasikan ketersediaan biologis protein atau asam amino rendah (Jenkins et al., 1996) akibat ternak mengkonsumsi ransum berkadar protein rendah (Botts $e t$ al., 1979).

Mikronutrien yang paling sering defisien pada sapi laktasi adalah kalsium dan fosfor sehingga unsur-unsur atau dikenal dengan nama mineral $\mathrm{Ca}$ dan $\mathrm{P}$ merupakan mineral paling utama untuk sapi laktasi (Tasse 1999). Mineral ini dibutuhkan untuk pembentukan tulang dan mineral dalam susu (Horst et al., 1994). Bila sapi laktasi kekurangan $\mathrm{Ca}$ dan $\mathrm{P}$ maka cadangan $\mathrm{Ca}$ dan $\mathrm{P}$ dalam jaringan tulang dapat dirombak untuk memenuhi kebutuhannya (Goff \& Horst, 1993). Kadar Ca dan $\mathrm{P}$ yang rendah dalam plasma mengindikasikan ketersediaan biologis $\mathrm{Ca}$ dan $\mathrm{P}$ rendah untuk mencukupi kebutuhan ternak (Tasse, 1999; Horst, 1986).

Berdasarkan uraian di atas maka penelitian telah dilakukan untuk mengetahui status nutrisi sapi laktasi berdasarkan kadar NEFA, albumin, kalsium $\left(\mathrm{Ca}^{2+}\right)$ dan fosfor $\left(\mathrm{P}_{\mathrm{i}}\right)$ dalam plasma di Kawasan Usaha Peternakan (KUNAK) Cibangbulang, Bogor.

\section{METODOLOGI}

\section{Lokasi Penelitian}

Penelitian dilakukan di Kawasan

Usaha Peternakan (KUNAK)

Cibungbulang Kabupaten Bogor.

Analisis komponen kimia dilakukan di Laboratorium Kimia Terpadu FMIPA IPB.

\section{Materi Penelitian}

Sapi perah laktasi yang digunakan untuk penelitian adalah sapi perah peranakan FH dalam periode awal laktasi dan kali beranak pertama dan kedua sebanyak 32 ekor yang menyebar dalam 12 kandang.

Ransum terdiri atas hijaun dan konsentrat. Hijauan yang digunakan untuk penelitian yaitu rumput gajah, sedangkan konsentrat merupakan produk pabrik pakan KPS Bogor dengan kadar protein kasar 14,42\% dan TDN 70,00\%. 


\section{Pengambilan Contoh Darah}

Pengambilan contoh darah dilakukan 3-4 jam setelah pemberian makanan pada pagi hari. Contoh darah diambil dari vena caudalis menggunakan venoject berisi heparin. Selanjutnya, venoject dibungkus dengan plastik lalu disimpan dalam termos es berisi es batu selama pengangkutan.

\section{Preparasi Contoh}

Setelah di Laboratorium, plasma darah dipisahkan dari butiran darah dengan cara disentrifugasi dengan kecepatan 3000 putaran per menit (rpm) selama 30 menit. Selanjutnya hasil sentrifugasi segera dipindahkan ke dalam tabung reaksi $10 \mathrm{ml}$ dengan menggunakan pipet lalu disimpan pada suhu $4^{\circ} \mathrm{C}$ untuk analisis komponen kimia darah.

\section{Pengukuran Bobot Badan}

Bobot badan diduga dari lingkar dada dengan menggunakan rumus Sutardi (1983) yaitu :

$$
\begin{aligned}
& \mathrm{B}= 601.8-9.033 \mathrm{~L}+0.04546 \mathrm{~L}^{2} \\
&\left(\mathrm{R}^{2}=0.96, \mathrm{P}<0.01\right) ; \\
& \mathrm{B}= \text { bobot badan }(\mathrm{kg}) \\
& \mathrm{L}= \text { lingkar dada }(\mathrm{cm}) \\
& \text { Pengukuran lingkar dada dilakukan }
\end{aligned}
$$
menggunakan pita ukur yang dilingkarkan diantara tulang rusuk ke 7 dengan ke 8 .

\section{Pengukuran Produksi Susu}

Pencatatan produksi susu dilakukan selama pengambilan contoh darah berlangsung. Pengukuran produksi susu dilakukan pada pagi hari dan sore hari. Susu hasil pemerahan setiap ekor sapi ditampung dalam milkcan, lalu ditimbang untu mengetahui jumlah susu yang dihasilkan per hari $\left(\mathrm{kg} . \mathrm{hr}^{-1}\right)$.

Pengukuran Kadar Asam Lemak Tidak Teresterifikasi (NEFA)

Prinsip pengukuran NEFA yaitu reaksi dengan enzim acyl-CoA synthetase, acyl-CoA oxydase, dan peroxydase. Larutan yang dibutuhkan 3 macam yaitu (1) larutan A, satu buah tablet mengandung CoA, ATP, Acyl-CoA synthetase, 4-amino antipirin dan stabiliser, dilarutkan dalam larutan mengandung $11 \mathrm{ml}$ buffer kaliumfosfat, $11 \mathrm{ml}$ bromohidrobenzoat, dan $11 \mathrm{ml}$ magnesiumkhlorida, (2) larutan $\mathrm{B}, 3 \mathrm{ml}$ $\mathrm{N}$-etilmaleinimida dan stabiliser, dan (3) larutan $\mathrm{C}$, satu tablet mengandung acylCoA oxydase dan stabiliser dilarutkan dalam larutan mengandung 0,6 $\mathrm{ml}$ acylCoA oxydase dan stabiliser.

Dua tabung reaksi disiapkan untu blanko dan contoh plasma. Tabung ke 1 untu blanko diisi dengan $1 \mathrm{ml}$ larutan A, dan 0,05 $\mathrm{ml}$ redist-water dikocok dan disimpan selama 15 menit. Setelah itu, tabung diisi lagi dengan $0,05 \mathrm{ml}$ larutan B. Absorbansi dari blanko dibaca dengan menggunakan spektrofotometer dengan panjang gelombang 578 atau $623 \mathrm{~nm}(=$ A1). Setelah absorbansi I dibaca, tabung blanko diisi dengan $0,05 \mathrm{ml}$ larutan $\mathrm{C}$ dan dikocok selama 15 menit. absorbansinya dibaca dengan panjang gelombang 578 atau $623 \mathrm{~nm}(=\mathrm{A} 2)$.

Tabung ke-2 diisi dengan $1 \mathrm{ml}$ larutan A dan 0,05 $\mathrm{ml}$ contoh darah lalu dikocok dan disimpan selama 15 menit. Absorbansi dari contoh plasma dibaca dengan menggunakan spektrofotometer dengan panjang gelombang 578 atau 623 nm (= A1). Setelah absorbansi I dibaca, tabung diisi lagi dengan $0,05 \mathrm{ml}$ larutan $\mathrm{C}$ dan dikocok selama 15 menit. Absorbansi contoh plasma dibaca lagi dengan menggunakan spektrofotometer dengan panjang gelombang 578 atau 623 $\mathrm{nm}(=\mathrm{A} 2)$.

$\Delta \mathrm{A}=\Delta \mathrm{Ac}-\Delta \mathrm{Ab} ; \mathrm{C}$ (konsentrasi NEFA, $\left.\mathrm{mEqL}^{-1}\right)=1,192 \mathrm{mmol} / 1$ plasma $\mathrm{x} \Delta \mathrm{A}$ $\Delta \mathrm{Ac}=\mathrm{A}_{2}-\mathrm{A}_{1}$ untuk contoh, $\Delta \mathrm{Ab}=\mathrm{A}_{2}$ - $A_{1}$ untuk blanko

Pengukuran Kadar Albumin Plasma

Prinsip pengukuran ini adalah reaksi albumin dengan bromokresol hijau membentuk kompleks pada $\mathrm{pH}$ 4,2 dan dilakukan secara fotometris. Larutan yang dibutuhkan yaitu larutan reage berisi $75 \mathrm{mmol} / 1$ buffer suksinat $\mathrm{pH} \mathrm{4,2}$ 
dan 0,05 mmol/1 bromokresol hijau brij 35 .

Tiga tabung reaksi dibutuhkan untuk blanko, standar, dan contoh. Tabung ke-1 diisi dengan $3 \mathrm{ml}$ larutan reagen, tabung ke-2 diisi dengan $3 \mathrm{ml}$ larutan reagen dan $0,01 \mathrm{ml}$ precinorm dan dikocok, dan tabung ke-3 diisi dengan $3 \mathrm{ml}$ larutan reagen dan $0,01 \mathrm{ml}$ contoh darah dan dikocok. Pengocokan isi tabung reaksi masing-masing 15 menit. Absorbansi dari blanko, standar dan contoh dibaca dengan menggunakan spektrofotometer dengan panjang gelombang $578 \mathrm{~nm}$ atau $623 \mathrm{~nm}$. Kadar albumin ditentukan dengan persamaan kadar albumin $(\mathrm{g} \%)=6 \mathrm{~g} \% \times \frac{A c-A b}{A s t}, \mathrm{Ac}$ $=$ absorbansi contoh, $\mathrm{Ab}=$ absorbansi blanko, Ast = absorbansi standar

\section{Pengukuran Kadar Kalsium Plasma}

Prinsip dari pengukuran kalsium darah yaitu terbentuknya suatu kompleks berwarna dari reaksi antara $\mathrm{Ca}^{2+}$ dan $\mathrm{O}^{+}$ kresol ftalein dalam larutan alkalis. Larutan yang dibutuhkan yaitu larutan standar, buffer, dan kromogen (reagen warna). Larutan standar berisi $2 \mathrm{mmol} / \mathrm{l}-$ $8 \mathrm{mg} / 100 \mathrm{ml}$, larutan buffer berisi 2amino-1 metilpropanol- (1) $3,5 \mathrm{ml} / 1 \mathrm{pH}$ 10,7; dan larutan kromogen berisi 8hidroksi hinolin $14 \mathrm{mmol} / 1, \mathrm{O}^{+}$-kresol ftalein kompleks $0,16 \mathrm{mmol} / 1$ dan $\mathrm{HCl}$ $0,06 \mathrm{~mol} / 1$.

Tiga tabung reaksi dibutuhkan untuk blanko, standar, dan contoh. Tabumg ke-1 diisi dengan $1 \mathrm{ml}$ larutan buffer dan $1 \mathrm{ml}$ larutan kromogen (1:1), lalu disimpan. Tabung ke-2 diisi dengan $0,04 \mathrm{ml}$ larutan standar dan 2,0 ml larutan kromogen, dan dikocok selama 60 menit. Tabung ke-3 diisi dengan 0,05 $\mathrm{ml}$ contoh plasma; 0,05 larutan buffer dan 2,0 $\mathrm{ml}$ larutan kromogen. Absorbansi dibaca dengan menggunakan spektofotometer dengan panjang gelombang $570 \mathrm{~nm}$. Kadar kalsium dalam plasma ditentukan dengan persamaan $\mathrm{Kadar}_{\mathrm{Ca}^{2+}}(\mathrm{mg} \%)=8 \mathrm{mg} \% \mathrm{x}$
$\frac{A c-A b}{A s t}, A c=$ absorbansi contoh, $\mathrm{Ab}=$ absorbansi balnko, dan Ast $=$ absorbansi standar.

Pengukuran Kadar Fosfor $\left(\mathbf{P}_{i}\right)$ Plasma

Prinsip dari pengukuran kadar fosfor plasma yaitu reaksi fosfor dengan molibdat dalam medium asam kuat membentuk kompleks. Larutan yang dibutuhkan yaitu larutan standar fosfor, larutan blanko, dan larutan reagen.

Tiga tabung reaksi dibutuhkan untuk blanko, standar, dan contoh. Tabung ke-1 diisi dengan 0,02 ml contoh plasma dan 2,00 $\mathrm{ml}$ reagen lalu dikocok selama 60 menit. Tabung ke-2 diisi dengan 2,00 $\mathrm{ml}$ reagen, dan tabung ke-3 diisi dengan 0,02 $\mathrm{ml}$ larutan standar dan $2,00 \mathrm{ml}$ larutan reagen. Absorbansi dibaca dengan menggunakan spektrofotometer pada panjang gelombang $340 \mathrm{~nm}$. Kadar fosfor dalam plasma ditentukan dengan persamaan Kadar $\mathrm{P}_{\mathrm{i}}(\mathrm{mg} \%)=10 \mathrm{mg} \% \times \frac{A c-A b}{A s t}, \mathrm{Ac}$ $=$ absorbansi contoh, $\mathrm{Ab}=$ absorbansi blanko, dan Ast = absorbansi standar.

\section{Analisis Data}

Uji " $\mathrm{t}$ " digunakan untuk menentukan kisaran kadar NEFA, albumin, kalsium dan fosfor plasma. Analisis korelasi digunakan untuk mengetahui hubungan antara peubah. Persamaan regresi digunakan untuk melihat model hubungan kadar NEFA, albumin, kalsium dan fosfor plasma dengan bobot badan dan produksi susu.

\section{HASIL DAN PEMBAHASAN}

\section{Korelasi antara Kali Beranak dengan Bobot Badan dan Produksi Susu}

Kali beranak menunjukkan frekuensi melahirkan dari sapi perah. Kali beranak ke-1 menunjukkan masa laktasi ke-1, dan kali beranak ke-2 menunjukkan masa laktasi ke-2, dan seterusnya (Schmidt et al., 1988). 
Korelasi antara kali beranak dengan bobot badan dan produksi susu tidak nyata (Tabel 1). Hal ini mengindikasikan bahwa masa laktasi ke-1 dan masa laktasi ke-2 tidak signifikan dipengaruhi oleh bobot badan dan produksi susu. Hal ini juga berimplikasi bahwa lama masa laktasi ke-1 dan ke-2 tidak signifikan dipengaruhi oleh bobot badan dan produksi susu. Meskipun bobot badan rendah dan tingkat produksi susu rendah, tidak akan mempengaruhi lama masa laktasi pada masa laktasi ke-1 dan ke-2. Faktor yang paling berperan untuk menentukan lama laktasi adalah pemenuhan kebutuhan nutrisi sapi laktasi. Menurut Nutrient Requirement Council (2001), sapi laktasi dalam kali beranak ke-1 dan kali beranak ke-2 masih mengalami pertumbuhan sehingga kebutuhan nutrisi untuk hidup pokok lebih tinggi 20\% untuk masa laktasi ke-1, dan $10 \%$ untuk masa laktasi ke-2 dari kebutuhan nutrisi untuk hidup pokok.

Hasil penelitian menunjukkan rataan dan kisaran produksi susu $8.64 \mathrm{~kg} . \mathrm{hr}^{-1}$ dan $7.29-9.99 \quad \mathrm{~kg} \cdot \mathrm{hr}^{-1}$. Hal in mengindikasikan bahwa asupan ransum dengan kadar TDN 70\% dan PK 14\% pada sapi laktasi dengan rataan bobot badan $377.29 \mathrm{~kg}$ mampu menghasilkan produksi susu lebih rendah dibandingkan dengan standar produksi susu yang mampu dihasilkan oleh sapi laktasi dengan asupan ransum yang sama (8.64 $\mathrm{kg} \cdot \mathrm{hr}^{-1}$ vs $13 \mathrm{~kg} \cdot \mathrm{hr}^{-1}$ ). Oleh karena itu, NRC (2001) telah merekomendasikan kebutuhan sai laktasi dengan tingkat produksi susu $10 \mathrm{~kg} \cdot \mathrm{hr}^{-1}$ yaitu TDN sekitar $64 \%$ dan protein kasar $14 \%$.

\section{Bobot Badan}

Sapi perah berbobot badan lebih tinggi mempunyai kemampuan menghasilkan produksi susu yang lebih tinggi dibandingkan dengan sapi perah berbobot badan lebih rendah (Tasse 1999). Rataan kisaran bobot badan sapi dalam masa laktasi ke-1 dan ke-2 yaitu $377.29 \mathrm{~kg}$ dan 354.72 - $394.87 \mathrm{~kg}$ dengan keragaman $12.92 \%$.

Bobot badan berkorelasi dengan produksi susu (Tabel 1). Hal ini berarti sapi dengan bobot badan sapi yang lebih tinggi akan menghasilkan susu yang lebih tinggi dibandingkan dengan bobot badan yang lebih rendah. Hasil penelitian ini memperkuat NRC (2001) bahwa bobot badan sapi laktasi berkorelasi kuat dengan tingkat produksi susu sehingga kebutuhan nutrisi sapi laktasi berdasarkan bobot badan dan produksi susu.

Tabel 1. Matriks Korelasi (r) antara Peubah

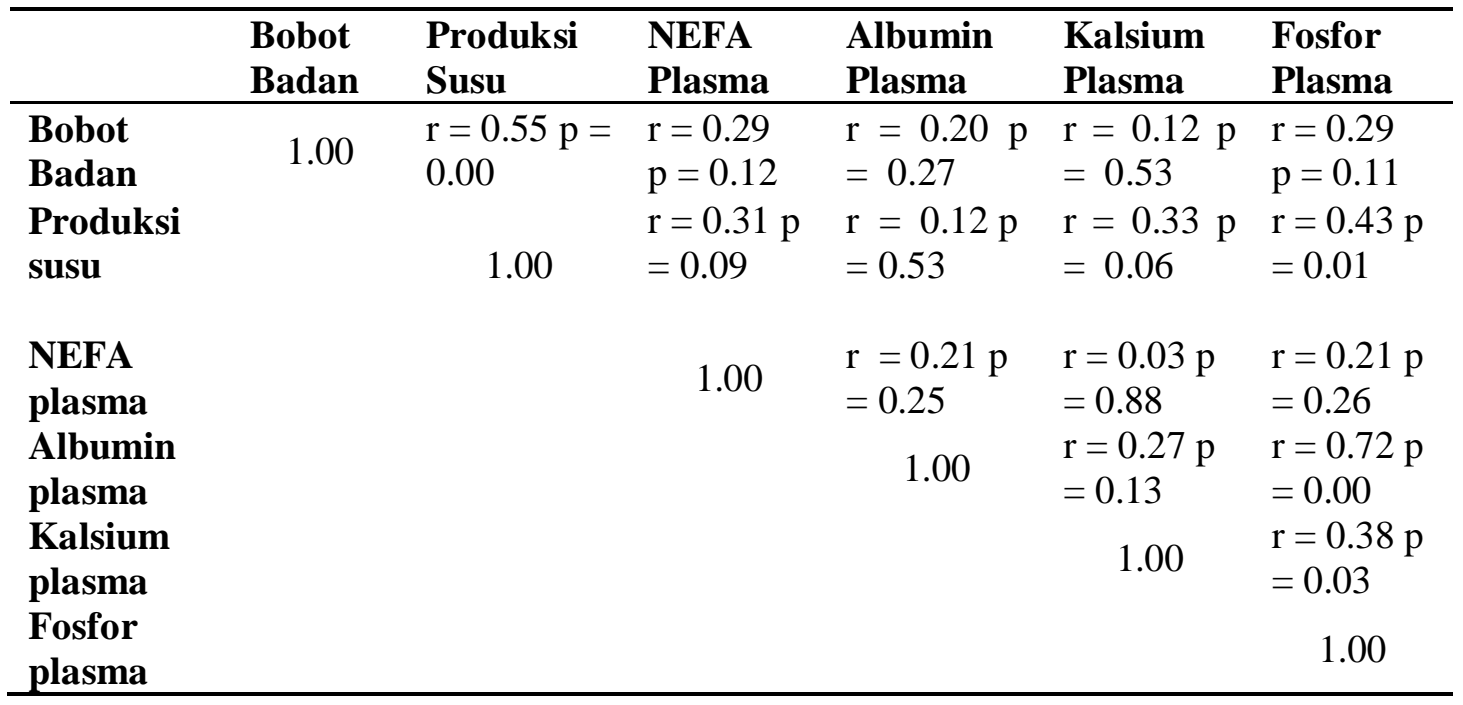




\section{Produksi Susu}

Selain periode laktasi, produksi susu dipengaruhi oleh ketersediaan nutrisi. Bila ketersediaan nutrisi tidak dapat mencukupi kebutuhan untuk menghasilkan susu, maka nutrisi hanya mampu untuk memenuhi kebutuhan hidup pokok atau hanya mampu untuk bertahan hidup sebagai hasil fermentasi karbohidrat pakan dalam rumen.

Selain waktu pengambilan contoh darah, faktor yang mempengaruhi konsentarsi NEFA plasma adalah kondisi fisiologis ternak misalnya bunting atau tidak bunting. Menurut Elliot et al (1994), kadar NEFA plasma dipengaruhi oleh beberapa faktor diantaranya kondisi fisiologis ternak.

\section{Status Nutrisi Energi}

Hasil penelitian menunjukkan konsentrasi NEFA dalam plasma lebih rendah $(\mathrm{P}<0.05)$ dari konsentrasi NEFA plasma sapi yang direkomendasikan Grum et al., (1996) (0.17 mEq..$^{-1}$ vs 0.34 $\left.\mathrm{mEq} . \mathrm{l}^{-1}\right)$. Hal ini menunjukkan perombakan depo lemak tubuh jaringan adiposa sapi laktasi setelah makan lebih rendah dibandingkan sebelum makan. Depo lemak tubuh dirombak jika terjadi peningkatan permintaan energi untuk memenuhi kebutuhan ternak. Sekitar 1.5 jam setelah makan, kadar NEFA plasma menurun karena peningkatan VFA yang

\section{Status Nutrisi Protein}

Konsentrasi albumin dalam plasma merupakan indeks yang baik untuk menggambarkan jumlah asam amino dalam darah karena protein yang berasal dari makanan dan cadangan protein tubuh misalnya pankreas, hati dan mukosa intestinal dapat diabsorbsi oleh darah. Hasil penelitian menunjukkan konsentrasi albumin plasma lebih rendah $(\mathrm{p}<0.01)$ dari konsentrasi albumin plasma yang direkomendasikan Ismudiono (1988) (2.69 g\% vs $3.00 \mathrm{~g} \%$ ).
Menurut Botts et al (1997). Bila kadar albumin plasma lebih rendah dari kadar normalnya maka hipoalbumin sudah terjadi dalam waktu yang lama dan jumlah kosumsi protein ransum sudah berlangsung lama.

Korelasi konsentrasi albumin plasma dengan konsentrasi fosfor plasma signifikan (Tabel 1). Konsentrasi albumin plasma diikuti dengan peningkatan konsentrasi fosfor plasma. Hal ini mengindikasikan bahwa peningkatan protein ransum harus diikuti dengan peningkatan kadar fosfor dalam ransum.

\section{Status Mineral Kalsium dan Fosfor}

Nutrisi mineral kalsium dan fosfor sangat dibutuhkan ternak sapi. Kalsium dan fosfor mempunyai fungsi saling membutuhkan dan sinergistik sebagai komponen pembentuk tulang (Tasse, 1999).

Hasil penelitian menunjukkan rataan dan kisaran konsentrasi $\mathrm{P}_{\mathrm{i}}$ plasma. Hal ini berarti ketersediaan biologis kalsium lebih tinggi dibandingkan dengan ketersediaan biologis fosfor. Meskipun konsentrasi $\mathrm{P}_{\mathrm{i}}$ plasma lebih rendah dibandingkan dengan konsentrasi $\mathrm{Ca}^{2+}$ plasma namun konsentrasi $P_{i}$ plasma lebih tinggi dari kisaran normal konsentrasi $\mathrm{P}_{\mathrm{i}}$ plasma sedangkan konsentrasi $\mathrm{Ca}^{2+}$ plasma lebih rendah kisaran normal konsentrasi $\mathrm{Ca}^{2+}$ plasma.

Hasil penelitian menunjukkan konsentrasi $\mathrm{Ca}^{2+}$ plasma lebih rendah dari konsentrasi $\mathrm{Ca}^{2+}$ plasma yang direkomendasikan NRC (2001) tetapi lebih tinggi dari konsentrasi $\mathrm{Ca}^{2+}$ plasma yang direkomendasikan Ismudiono (1988) (Tabel 2). Hal ini mengindikasikan bahwa ketersediaan biologis kalsium lebih rendah dari kebutuhan kalsium sapi laktasi dengan

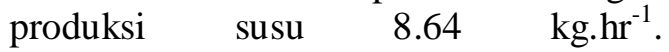


Tabel 2. Rataan dan Kisaran Konsentrasi NEFA, Albumin, Kalsium dan Fosfor Plasma

\begin{tabular}{|c|c|c|c|}
\hline Peubah & Rataan & Kisaran & Kisaran \\
\hline $\begin{array}{l}\text { Konsentrasi NEFA } \\
\left.\text { Plasma (mEq. }{ }^{-1}\right)\end{array}$ & 0.17 & $0.11-0.22$ & $0.17^{1}$ \\
\hline $\begin{array}{l}\text { Konsentrasi } \\
\text { Albumin Plasma } \\
(\mathrm{g} \%)\end{array}$ & 2.69 & $2.51-2.87$ & $3.00-3.80^{2}$ \\
\hline $\begin{array}{l}\text { Konsentrasi } \\
\text { Kalsium Plasma } \\
(\mathrm{mg} \%)\end{array}$ & 9.39 & $8.90-9.88$ & $\begin{array}{c}7.42-7.79^{2} \\
9.00-11.00^{3}\end{array}$ \\
\hline $\begin{array}{l}\text { Konsentrasi Fosfor } \\
\text { Plasma (mg\%) }\end{array}$ & 8.60 & $8.10-9.10$ & $4.00-8.00^{3}$ \\
\hline
\end{tabular}

Grum et al., (1996)

${ }^{2}$ Ismudiono (1988)

${ }^{3} \mathrm{NRC}(2001)$

Oleh karena itu status nutrisi mineral kalsium kurang. Defisiensi mineral kalsium dipengaruhi beberapa faktor diantaranya kadar kalsium ransum rendah, konsumsi kalsium rendah, absorbsi kalsium rendah, dan kelarutan kalsium ransum rendah.

Hasil penelitian konsentrasi $\mathrm{Pi}$ plasma lebih tinggi $(\mathrm{P}<0.01)$ dari konsentrasi $\mathrm{P}_{\mathrm{i}}$ plasma yang direkomendasikan NRC (2001). Hal ini menunjukkan bahwa ketersediaan biologis fosfor lebih tinggi dari kebutuhan fosfor sapi laktasi dengan produksi susu $8.64 \mathrm{~kg} \cdot \mathrm{hr}^{-1}$. Hal ini mengindikasikan bahwa status mineral fosfor dalam kategori cukup. Kemampuan fosfor ransum untuk memenuhi kebutuhan fosfor ternak ditentukan oleh kadar fosfor dalam ransum dan saliva.

Hubungan Konsentrasi NEFA Plasma dengan Bobot Badan dan Produksi Susu

Konsentrasi NEFA dalam plasma tidak signifikan dipengaruhi oleh bobot badan dan tingkat produksi susu (Tabel 3). Sapi perah laktasi yang digunakan untuk penelitian dalam masa laktasi ke-1 dan ke-2. Dalam masa pertumbuhan, berukuran kecil dengan rataan bobot

badan $377 \mathrm{~kg}$ belum mencapai bobot badan dewasa optimal sehingga laju perombakan-perombakan jaringan tubuh masih rendah meskipun konsumsi ransum rendah.

Konsentrasi asam lemak tidak teresterifikasi NEFA dalam plasma bukan indikator status nutrisi energi pada sapi laktasi dalam masa laktasi ke-1 dan ke-2, jika kebutuhan nutrisi sapi perah laktasi berdasarkan bobot badan dan produksi susu harian. Menurut Mc Nawara et al., (1995), lipolisis cadangan lemak dalam tubuh sapi perah selama awal laktasi untuk masa laktasi ke-1 dan ke-2 tidak nyata mempengaruhi bobot badan.

Hubungan antara Konsentrasi Albumin Plasma dengan Bobot Badan dan Produksi Susu

Konsentrasi albumin dalam plasma tidak signifikan dipengaruhi oleh bobot badan dan produksi susu (Tabel 3). Hal ini menunjukkan albumin bukan merupakan hasil perombakan cadangan protein dalam tubuh sapi perah dalam masa laktasi ke-1 dan ke-2. Selanjutnya, albumin dalam darah tidak mengindikasikan status nutrisi protein sapi perah laktasi. Oleh karena itu, ketersediaan protein dalam ransum 
Tabel 3. Model Linier antara Konsentrasi NEFA, Albumin, Kalsium dan Fosfor dalam Plasma dengan Bobot Badan dan Produksi Susu.

\begin{tabular}{|c|c|c|}
\hline Komponen Darah & $\mathbf{X}_{\mathbf{i}}$ & $\mathbf{Y}=\mathbf{a}+\mathbf{b x}$ \\
\hline $\begin{array}{l}\text { Konsentrasi NEFA } \\
\text { Plasma }\end{array}$ & 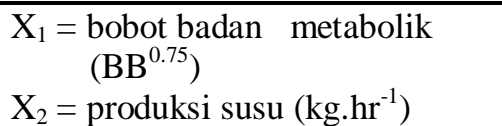 & $\begin{array}{l}Y=0.160 X_{1}+0.215 X_{2} \\
\left(S_{b}=0.97, P>0.05\right)\end{array}$ \\
\hline $\begin{array}{l}\text { Konsentrasi Albumin } \\
\text { Plasma }\end{array}$ & $\begin{array}{l}\mathrm{X}_{1}=\underset{\text { bobot badan metabolik }}{\left(\mathrm{BB}^{0.75}\right)} \\
\mathrm{X}_{2}=\text { produksi susu }\left(\mathrm{kg} \cdot \mathrm{hr}^{-1}\right)\end{array}$ & $\begin{array}{l}Y=0.197 X_{1}+0.006 X_{2} \\
\left(S_{b}=0.99, P>0.05\right)\end{array}$ \\
\hline $\begin{array}{l}\text { Konsentrasi Kalsium } \\
\text { Plasma }\end{array}$ & $\begin{array}{l}\mathrm{X}_{1}=\underset{\text { bobot badan metabolik }}{\left(\mathrm{BB}^{0.75}\right)} \\
\mathrm{X}_{2}=\text { produksi susu }\left(\mathrm{kg} \cdot \mathrm{hr}^{-1}\right)\end{array}$ & $\begin{array}{l}Y=-0,099 X_{1}+0.389 X_{2} \\
\left(S_{b}=0.97, P>0.05\right)\end{array}$ \\
\hline $\begin{array}{l}\text { Konsentrasi Fosfor } \\
\text { Plasma }\end{array}$ & $\begin{array}{l}\mathrm{X}_{1}=\underset{\text { bobot badan metabolik }}{\left(\mathrm{BB}^{0.75}\right)} \\
\mathrm{X}_{2}=\text { produksi susu }\left(\mathrm{kg} \cdot \mathrm{hr}^{-1}\right)\end{array}$ & $\begin{array}{l}Y=0.072 X_{1}+0.394 X_{2} \\
\left(S_{b}=0.93, P<0.05\right)\end{array}$ \\
\hline
\end{tabular}

sangat dibutuhkan untuk mencukupi kebutuhan sapi perah dalam masa laktasi awal.

Sapi perah dalam periode laktasi terutama pada periode awal laktasi minggu pertama sampai minggu delapan, sangat membutuhkan protein untuk mendukung produksi susu per hari (produksi susu harian), dan produksi komponen susu misalnya kasein. Kebutuhan protein pada ternak biasanya didasarkan pada tingkat produksi. Semakin tinggi produksi susu seekor sapi perah maka kebutuhan protein semakin tinggi, sehingga kadar protein dalam ransum perlu ditingkatkan untuk mendukung produksi susu.

\section{Hubungan antara Konsentrasi Kalsium dan Fosfor Plasma dengan Produksi Susu}

Konsentrasi kalsium dalam plasma tidak signifikan dipengaruhi oleh bobot badan dan produksi susu, sedangkan konsentrasi fosfor dalam plasma signifikan dipengaruhi oleh bobot badan dan produksi susu (Tabel 3).

Hal ini menunjukkan ketersediaan fosfor dalam darah merupakan faktor yang menentukan untuk mendukung produksi susu. Meskipun konsentrasi kalsium tidak signifikan dipengaruhi oleh bobot badan dan produksi susu, kebutuhan kalsium lebih tinggi dibandingkan dengan kebutuhan fosfor untuk mendukung bobot badan. Sedangkan kebutuhan kalsium dan fosfor relatif sama pada tingkat produksi yang sama. Namun, defisiensi kalsium berdampak pada penurunan bobot badan. Sebaliknya, kecukupan kalsium berdampak pada peningkatan produksi susu.

Hasil penelitian mengindikasikan bahwa rasio kebutuhan kalsium dan fosfor untuk sapi perah perlu ditinjau kembali dan kajian yang lebih luas. Penerapan kecukupan kebutuhan mineral $\mathrm{Ca}$ dan $\mathrm{P}$ dengan rasio 2 : 1 dalam ransum sapi perah, sedangkan hasil penelitian mengindikasikan rasio kecukupan kebutuhan mineral $\mathrm{Ca}$ dan $\mathrm{P}$ adalah $1: 1$ bila berdasarkan bobot badan, dan atau produksi susu.

\section{KESIMPULAN}

Berdasarkan konsentrasi NEFA, albumin, kalsium dan fosfor plasma, sapi perah laktasi dalam masa laktasi awal dengan pemberian konsentrat berkadar protein kasar $17 \%$ dan TDN 70\%, dalam status nutrisi energi, mineral $\mathrm{Ca}$ dan $\mathrm{P}$ dalam kategori cukup, yang berarti konsentrat berkadar protein kasar 17\% dan TDN $70 \%$ mampu mencukupi kebutuhan energi dan mineral $\mathrm{Ca}$ dan $\mathrm{P}$ sapi laktasi dengan produksi susu per hari kurang dari 10 liter. 


\section{Ucapan Terima Kasih}

Penulis menyampaikan terima kasih kepada ketua KPS Bogor, Manager KUNAK, Laboran Laboratorium Kimia Terpadu FMIPA, dan teman-teman Dairy Science, Feed and Nutrition atas fasilitas dan dukungannya pada keberhasilan penelitian ini.

\section{DAFTAR PUSTAKA}

Baldwin, R.L, R.S. Emery and J.P. Mc Namara. 1994. Metabolic relationships in the supply of nutrients for milk synthesis: intregrative modeling. J. Dairy Sci. 77: 2821-2826.

Belyea, R.L., Babbitt, H.T. Sedgwick, and G.M. Zinn. 1986. Body protein losses estimeted by nitrogen balance and potassium- 40 counting. J. Dairy Sci. 69: 18171823.

Botts, R.T., R.W. Hemkein and L.S Bull. 1979. Protein reserves in lactating dairy cow. J. Dairy Sci. 62: 433449.

Fronk, T.J., L.H. Schultz and A.R. Hardie. 1980. Effect of dry period over conditioning on subsequent metabolic disorders and performance of dairy cows. J. Dairy Sci. 63: 1080-1090.

Grum, D.E., J.K. Drackley, L.R. Hansen and J.D. Cremin. 1996. Production, digestion and hepatic metabolism of dairy cows fed increased energy from fat or concentrate. J. Dairy Sci. 79: 18361840 .

Horst, R.L. 1986. Regulation of calcium and phosphorus homeostasis in the dairy cow. J. Dairy Sci. 69: 604616.
Horst., R.L., J.P. Goff and T.A. Reinhardt. 1994. Calcium and Vitamin D metabolism in the dairy cow. J. Dairy Sci.77 (7): 19361946.

Ismudiono. 1988. Pengaruh status gizi yang digambarkan oleh beberapa komponen darah terhadap reproduksi dan produksi sapi perah. Disertasi. Fakultas Pascasarjana. Institusi Pertanian. Bogor.

Mc. Namara, J.P. and J.K Hillers. 1986. Regulation of bovine adipose tissues metabolism during lactation. :2. Lipolisis response to milk production and energy intake. J. Dairy Sci. 69: 3042-3050.

Mc. Namara, J.P., J.H Horrison, R.L. Kincaid and S.S. Walner. 1995. Lipid metabolism in adipose tissue of cow fed high fat diets during lactation. J. Dairy Sci.76: 27822796.

National Research Council. 2001. Nutrient Requirement of Dairy Cattle. th.ed. Nat. Acad. Press, Washington, D.C

Swenson, M.J. 1984. Physiology of Domestic Animal. $10^{\text {th }}$. ed Cornell University Press Ltd. Ithaca and London.

Tasse, A.M. 2014. Asam Lemak Pada Ternak. Cetakan I. BP UNM, Makassar. 